ResearCh Article

Corrected Article Published July 19, 2018

Correction: This is a corrected version of this article, published on July 19, 2018. The original version of this article, published on April 26, 2018, was missing an informed consent statement.

\title{
Biomarkers Associated with Death After Initiating Treatment for Tuberculosis and HiV in Patients with Very Low $\mathrm{CD}_{4}$ Cells
}

\section{AUTHORS}

Fred R. Sattler ${ }^{1}$, Daniel Chelliah ${ }^{1}$, Xingye $\mathrm{Wu}^{2}$, Alejandro Sanchez ${ }^{1}$, Michelle A. Kendall ${ }^{2}$, Evelyn Hogg $^{3}$, David Lagat ${ }^{4}$, Umesh Lalloo ${ }^{5}$, Valdilea Veloso ${ }^{6}$, Diane V. Havlir ${ }^{7}$, Alan Landay ${ }^{8}$

\section{AFFILIATED INSTITUTIONS}

${ }^{1}$ Keck School of Medicine of the University of Southern California, Los Angeles, California ${ }^{2}$ Harvard School of Public Health, Boston, Massachusetts

${ }^{3}$ Social \& Scientific Systems Inc., Silver Springs, Maryland

${ }^{4}$ Moi University Clinical Research Center, Eldoret, Kenya

${ }^{5}$ Enhancing Care Foundation, Durban University of Technology, Durban, South Africa

${ }^{6}$ Evandro Chagas National Institute of Infectious Diseases, Oswaldo Cruz Foundation, Rio de

Janeiro, Brazil

${ }^{7}$ University of California San Francisco, San Francisco, California

${ }^{8}$ Rush Presbyterian Medical Center, Chicago, Illinois

\section{CORRESPONDING AUTHOR}

Fred Sattler

DOI

Keck School of Medicine of the University of Southern California

10.20411/pai.v3i1.235

IRD Building Room 434

2020 Zonal Avenue

Los Angeles, CA 90033

Telephone: 323-409-4444

\section{SUGGESTED CITATION}

Sattler FR, Chelliah D, Wu X, Sanchez A, Kendall MA, Hogg E, Lagat D, Lalloo U, Veloso V, Havlir DV, Landay A. Biomarkers Associated with Death After Initiating Treatment for Tuberculosis and HIV in Patients with Very Low CD4 Cells. Pathogens and Immunity. 2018;3(1):46-62. doi: 10.20411/pai.v3i1.235 


\section{ABSTRACT}

Background: The risk of short-term death for treatment naive patients dually infected with $M y c o-$ bacterium tuberculosis and HIV may be reduced by early anti-retroviral therapy. Of those dying, mechanisms responsible for fatal outcomes are unclear. We hypothesized that greater malnutrition and/or inflammation when initiating treatment are associated with an increased risk for death.

Methods: We utilized a retrospective case-cohort design among participants of the ACTG A5221 study who had baseline $\mathrm{CD} 4<50$ cells $/ \mathrm{mm}^{3}$. The case-cohort sample consisted of 51 randomly selected participants, whose stored plasma was tested for C-reactive protein, cytokines, chemokines, and nutritional markers. Cox proportional hazards models were used to assess the association of nutritional, inflammatory, and immunomodulatory markers for survival.

Results: The case-cohort sample was similar to the 282 participants within the parent cohort with CD4 $<50$ cells $/ \mathrm{mm}^{3}$. In the case cohort, $7(14 \%)$ had BMI $<16.5\left(\mathrm{~kg} / \mathrm{m}^{2}\right)$ and $17(33 \%)$ had BMI $16.5-18.5\left(\mathrm{~kg} / \mathrm{m}^{2}\right)$. Risk of death was increased per $1 \mathrm{IQR}$ width higher of $\log _{10}$ transformed level of C-reactive protein (adjusted hazard ratio $(\mathrm{aHR})=3.42[95 \% \mathrm{CI}=1.33-8.80], P=0.011$ ), interferon gamma $(\mathrm{aHR}=2.46[\mathrm{CI}=1.02-5.90], P=0.044), \mathrm{MCP}-3$ (3.67 [CI = 1.08-12.42], $P=0.037)$, and with IL-15 ( $\mathrm{aHR}=2.75$ [CI $=1.08-6.98], P=0.033)$ and IL-17 $(\mathrm{aHR}=3.99$ [CI = -1.06-15.07], $P=0.041$ ). BMI, albumin, hemoglobin, and leptin levels were not associated with risk of death.

Conclusions: Unlike patients only infected with $M$. tuberculosis for whom malnutrition and low BMI increase the risk of death, this relationship was not evident in our dually infected patients. Risk of death was associated with significant increases in markers of global inflammation along with soluble biomarkers of innate and adaptive immunity.

\section{KEYWORDS}

Mycobacterium tuberculosis; Human Immunodeficiency Virus; Timing of antiretroviral therapy; Predictors of mortality; Nutrition biomarkers; Innate immunity; Adaptive immunity

\section{BACKGROUND}

World-wide, tuberculosis remains the most common cause for hospitalization of HIV-infected patients with death occurring in $10 \%-30 \%$ of these patients $[1,2]$. Recent studies indicate that death from tuberculosis can be reduced in HIV-infected treatment-naive patients by initiating anti-retroviral therapy (ART) earlier rather than later [3-5]. However, predictors of death in the ensuing months after ART is initiated have not been investigated in this co-infected population. In patients without HIV, malnutrition contributes to the incidence and severity of pulmonary tuberculosis [6-8]. Furthermore, wasting with very low BMI, malnutrition, and advancing age have been associated with a greater risk of death than for patients with better nutritional status, especially in developing countries [9-11].

Patients co-infected with tuberculosis and HIV often have worse nutritional status (inadequate intake of nutritional energy) with wasting (low BMI) and more cachexia (greater loss of lean tissue due to inflammation caused by HIV infection) than HIV-negative persons with tuberculosis [12-14]. Low CD4 cell counts are also associated with greater wasting and early mortality in persons co-infected with M. tuberculosis and HIV [15-17]. Wasting (low BMI) due to malnutrition 
and cachexia caused by inflammation in persons with HIV (without tuberculosis), which is often due to uncontrolled viral replication, are risk factors per se for death [6, 17-23]. Furthermore, poor nutritional status and low leptin (decreased energy intake) may suppress cellular immunity thereby increasing the risk for adverse outcomes. Regardless of the cause of wasting and cachexia, death has been extrapolated to body weight of $66 \%$ or body cell mass of $54 \%$ of pre-morbid levels in persons with HIV [24]. However, the exact mechanisms contributing to death in persons co-infected with M. tuberculosis and HIV have not been determined.

The conceptual underpinning for this investigation is that death in HIV-positive individuals acutely infected with $M$. tuberculosis and who are initiating treatment for the first time with combination ART is due in part to malnutrition from impaired energy intake. We also postulate that this co-infection induces an intense, self-perpetuating cytokine cascade beginning with the local production of TNF $\alpha$ and interferon gamma (IFN $\gamma$ ) in response to M. tuberculosis in the lung. These cytokines induce cellular signal transduction that promotes $\mathrm{NF \kappa} \beta$ nuclear translocation and transcription of gene products [25], ultimately resulting in the production and release of a broad array of pro-inflammatory cytokines into the systemic circulation, that also enhance HIV viral replication systemically and locally in the lung $[\underline{26}, \underline{27}]$.

HIV infection independently stimulates nuclear transcription through $N F \kappa \beta$, which upregulates both viral replication and translation of gene products to increase production and release pro-inflammatory mediators $[\underline{18}, \underline{28}]$. In addition, high levels of viral replication are associated with greater wasting $[\underline{19}, \underline{29}]$ and are expected to impair immune recovery including pathogen specific immunity for M. tuberculosis. These 2 infections together are thus expected to cause auto-amplification of pro-inflammatory cytokine pathways, thereby resulting in more severe cachexia with loss of lean tissue mass and thus enhanced risk of death $[\underline{20}, \underline{21}]$, especially in the early period of treatment for tuberculosis [토].

In the AIDS Clinical Trials Group Study A5221 in which ART was begun early or deferred by approximately 1 month, there was an increased incidence of death plus new opportunistic infection in the ensuing year in participants with baseline CD4 counts $<50$ cells $/ \mathrm{mm}^{3}$ who delayed ART by 1 month. The a priori goal of this secondary objective of A5221 was to determine if baseline measures of 1) nutrition or 2) inflammation and immune activation could be related to death in the participants initiating therapy for HIV and tuberculosis who had low CD4 counts $\left(<50\right.$ cells $\left./ \mathrm{mm}^{3}\right)$ [3].

\section{METHODS}

To address our first hypothesis that poor nutritional status contributed to death in the study cohort, $\mathrm{BMI}$, albumin, hemoglobin, and leptin levels were compared in participants who died versus those who survived. For the second postulate that inflammation and/or immune activation contributed to death, levels of C-reactive protein (CRP), a number of pro-inflammatory cytokines, anti-inflammatory cytokines/ligands, chemokines, and measures of the innate and/or adaptive immune responses were compared in participants who died versus those who survived within the case-cohort sample. All participants provided informed consent prior to enrollment in the ACTG A5221 study.

\section{Study design}

Our investigation used a retrospective case-cohort design: a random sample was drawn from the parent study and then all cases that were not selected in the random sample were added to make 
the full case-cohort sample. The case-cohort design combines the advantages of a prospective cohort study and the efficiency of a case-control design. It is most useful in analyzing time to failure in a cohort in which failure is rare. For the purposes of this investigation, a case (failure) was defined as death occurring in the 48 weeks after study enrollment.

\section{Study population}

The parent cohort is based on the ACTG A5221 study, which was a randomized, open-label 48week investigation comparing earlier versus later ART in persons with HIV-1 infection and suspected or documented pulmonary tuberculosis and with CD 4 counts of $<250 \mathrm{cells} / \mathrm{mm}^{3}$. A total of 806 participants were eligible and enrolled in A5221. Of these, 282 participants had baseline CD4 (average CD4 count over screening and study entry visits) $<50$ cells $/ \mathrm{mm}^{3}[\underline{3}]$.

For this investigation, a random cohort of 100 participants with baseline CD $4<50$ cells $/ \mathrm{mm}^{3}$ was drawn from the 282 parent-study cohort. Of these, 44 participants had sufficient baseline plasma samples stored for biomarker evaluation; 11 of the 44 died during the study. An additional 21 cases of death from the parent cohort with CD $4<50$ cells $/ \mathrm{mm}^{3}$ were also included, but only 7 had sufficient baseline plasma samples available for testing. Thus, a total of 51 participants made up the case-cohort sample for this investigation (see Figure 1).

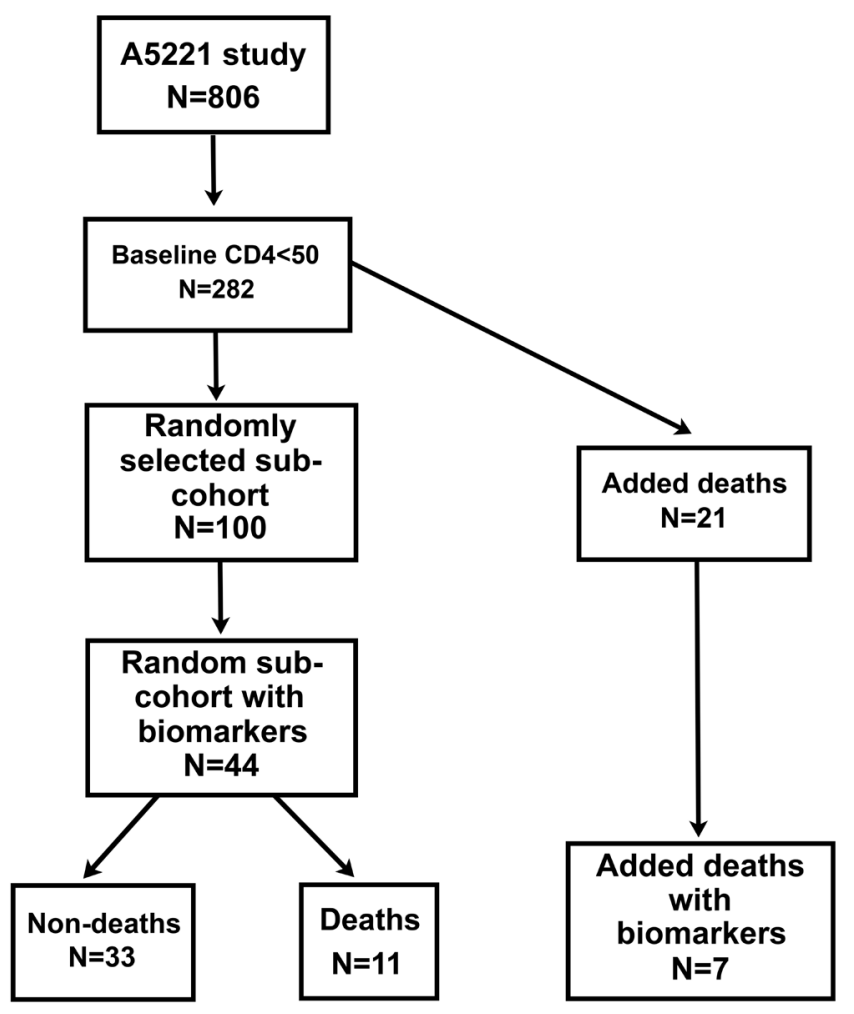

Figure 1. Schema for Selection of the Case-Cohort. A random cohort consisting of 100 participants was drawn from a subset of the 806 study participants who had CD $4<50$ cells $/ \mathrm{mm} 3(\mathrm{n}=282)$. Plasma was only available for 44 participants in this subset, 11 of whom died. This cohort was enriched by selecting 21 additional cases from the 282 participants having CD4 $<50$ cells $/ \mathrm{mm} 3$ (not in the random cohort of 100) who also died, but only seven of these had plasma. The total case-cohort for the study therefore included 51 participants 


\section{Biomarkers}

For the cohort reported herein, plasma stored at -80C was tested for C-reactive protein, cytokines, chemokines, and nutritional markers. These included the pro-inflammatory cytokines (TNFa, IL-6, INF $\gamma$, MIP-1 $\alpha$ ), anti-inflammatory cytokines (IL-10, IL-1ra), cytokines involved in innate and adaptive immunity (IL-15, IL-17, respectively), chemokines (MCP-1, MCP-3, IP-10), and nutritional markers (adiponectin, leptin). Levels were quantified using a Milliplex multi-analyte profiling assay (Millipore) in the University of Southern California Cancer Center Immunology Core Laboratory.

\section{Statistical analysis}

Testing and estimation of the effect of each baseline biomarker on time to death were performed using Cox proportional hazards regression models adjusted for baseline CD4 cell count and HIV viral load. The biomarkers were log 10 transformed and then modeled per $1 \mathrm{IQR}$ increment in the Cox models. The Barlow weighting scheme was used to account for the case-cohort sampling. The Efron method was used to handle ties in failure times. Event times were calculated as the exact days from randomization date to the date of death.

Adjustments were not made for multiple comparisons. All analyses used SAS 9.4 with results considered significant when $P<0.05$.

\section{RESULTS}

At baseline, the case-cohort of 51 participants was comparable to the larger population of 282 participants in the parent cohort with CD4 cell count $<50$ cells $/ \mathrm{mm}^{3}$, with respect to age, sex, race, CD4 counts, and HIV viral load ( $P>0.05$ for all comparisons; data not shown). Of further importance, there was no difference in the proportion of participants randomized to earlier versus later ART.

For the cohort of 51 participants, the 33 who survived were not different from the 18 who died, in baseline characteristics that included age, sex, CD4 cell counts, HIV viral load, BMI, hemoglobin, albumin, adiponectin, leptin, or treatment assignment, except that the median age of the patients who died was 9 years older $(P=0.033$; Table 1). Of note, $7(14 \%)$ participants had BMI $<16.5 \mathrm{~kg} / \mathrm{m}^{2}$ and $17(33 \%)$ had BMI $16.5-18.5 \mathrm{~kg} / \mathrm{m}^{2}$. The causes of death and week of death (in parentheses) in the ensuing year after randomization were disseminated tuberculosis $(2,4)$, gastroenteritis $(3,5,11)$, pulmonary tuberculosis $(4,10)$, acute renal failure $(5)$, bacterial pneumonia $(8,34)$, cryptococcal meningitis (9), bacterial meningitis (13), bacterial sepsis (14), peritonitis (11), intra-cranial hypertension (16), gunshot wounds (24), tuberculous meningitis (40), and no information (23). Death could not be related to treatment assignment (early versus deferred ART) in this small cohort. 
Table 1: Baseline Clinical Characteristics and Markers of Nutrition

\begin{tabular}{|c|c|c|c|c|}
\hline Median $(\mathrm{Q} 1, \mathrm{Q3})$ or $\mathrm{N}(\%)$ & $\begin{array}{c}\text { Total } \\
(\mathrm{N}=\mathbf{5 1})\end{array}$ & $\begin{array}{l}\text { Deaths } \\
(N=18)\end{array}$ & $\begin{array}{l}\text { Non-deaths } \\
\qquad(\mathbf{N}=\mathbf{3 3})\end{array}$ & $P$-Value ${ }^{\text {a }}$ \\
\hline Age (years) & $35(30,42)$ & $42(34,45)$ & $33(30,41)$ & 0.033 \\
\hline Sex (male) & $39(76 \%)$ & $13(72 \%)$ & $26(79 \%)$ & 0.732 \\
\hline CD4 count $\left(\right.$ cells $\left./ \mathrm{mm}^{3}\right)$ & $25(13,36)$ & $25(8,34)$ & $25(15,38)$ & 0.340 \\
\hline HIV RNA $\left(\log _{10}\right.$ copies/ml) & $5.37(5.00,5.77)$ & $5.40(5.01,5.78)$ & $5.35(5.00,5.74)$ & 0.771 \\
\hline Body Mass Index (BMI, $\mathrm{kg} / \mathrm{m}^{2}$ ) & $18.6(17.3,20.6)$ & $18.3(17.1,20.3)$ & $19.2(17.6,21.1)$ & 0.955 \\
\hline$<16.5$ & $7(14 \%)$ & $2(11 \%)$ & $5(15 \%)$ & 0.559 \\
\hline $16.5-18.5$ & $17(33 \%)$ & $8(44 \%)$ & $9(27 \%)$ & \\
\hline$>18.5$ & $27(53 \%)$ & $8(44 \%)$ & $19(58 \%)$ & \\
\hline Hemoglobin $(\mathrm{g} / \mathrm{dl})$ & $9.70(8.40,10.40)$ & $9.45(8.40,10.10)$ & $9.90(8.40,10.40)$ & 0.484 \\
\hline Albumin (g/dl) & $2.68(2.38,3.30)$ & $2.61(2.43,3.00)$ & $2.77(2.30,3.38)$ & 0.365 \\
\hline Adiponectin (mg/dl) & $3.50(1.86,6.88)$ & $3.48(1.95,5.00)$ & $3.50(1.86,7.11)$ & 0.400 \\
\hline Leptin (ng/ml) & $0.20(0.02,0.85)$ & $0.21(0.02,0.71)$ & $0.06(0.02,1.14)$ & 0.963 \\
\hline $\mathrm{CD} 4 / \mathrm{CD} 8$ ratio $^{\mathrm{b}}$ & $0.07(0.05,0.14)$ & $0.05(0.02,0.11)$ & $0.07(0.05,0.14)$ & 0.517 \\
\hline Treatment arm (immediate) & $26(51 \%)$ & $9(50 \%)$ & $17(52 \%)$ & $>0.99$ \\
\hline
\end{tabular}

a) Fisher's exact test was used for analysis of sex, BMI group, and treatment arm; T-test with unequal variance was used for others; b) Due to missing data, sample sizes were $\mathrm{N}=32, \mathrm{~N}=10$, and $\mathrm{N}=22$, respectively.

For measures of nutrition, hazard ratios for average BMI, low BMI, serum hemoglobin, serum albumin, and leptin were not significant risk factors for death, although there was a trend for increased risk of death with advancing age (adjusted hazard ratio $(\mathrm{HR})$ per 5 years increment $=1.32$ [95\% CI 0.97-1.79], $P=0.076$, Table 2). Global inflammation measured by levels of C-reactive protein (CRP), pro-inflammatory cytokines (IL-6, TNFa, INF $\gamma$, IL-15, and IL-17) and chemokines MCP-3 and MIP was significantly higher in participants who died (Table 3). Increased risk of death was significantly associated with CRP (adjusted HR per 1 IQR width increment $=3.42$ [95\% CI 1.33-8.80], $P=0.011$; Table 3), but the only pro-inflammatory cytokine associated with significant risk of death was IFN $\gamma$ (adjusted $\mathrm{HR}=2.46$ [95\% CI 1.02-5.90], $P=0.044$ ). MCP-3 was associated with risk of death (adjusted $\mathrm{HR}=3.67$ [95\% CI 1.08-12.42], $P=0.037$ ), but MCP-1 was not. Global measures of the innate (IL-15) and adaptive (IL-17) immune responses were both strongly associated with risk of death (adjusted HRs $=2.75$ [95\% CI 1.08-6.98], 3.99 [95\% CI 1.06-15.07]; $P=0.033,0.041$, respectively). 
Table 2: Risk of Death Associated with Age, Sex, and Baseline Markers of Nutrition

\begin{tabular}{lcccc}
\hline & $\begin{array}{c}\text { Hazard } \\
\text { Ratio } \\
\text { (HR) }\end{array}$ & $\begin{array}{c}\mathbf{9 5 \%} \text { Lower } \\
\text { Confidence } \\
\text { Limit for HR }\end{array}$ & $\begin{array}{c}\text { 95\% Upper Confi- } \\
\text { dence Limit for HR }\end{array}$ & $\begin{array}{c}\text { P-Value Wald } \\
\text { Test }\end{array}$ \\
\hline Age (per 5 years increment) & 1.32 & 0.97 & 1.79 & 0.076 \\
Sex (male) & 0.74 & 0.22 & 2.51 & 0.631 \\
BMI (kg/m $\left.{ }^{2}\right)$ & 1.07 & 0.81 & 1.42 & 0.646 \\
BMI (ref: $>18.5)<16.5$ & 0.58 & 0.07 & 4.54 & 0.604 \\
BMI (ref: $>18.5) ~ 16.5-18.5$ & 1.42 & 0.37 & 5.41 & 0.608 \\
Hemoglobin $(\mathrm{g} / \mathrm{dl})$ & 0.90 & 0.70 & 1.15 & 0.402 \\
Albumin $(\mathrm{g} / \mathrm{dl})$ & 0.78 & 0.38 & 1.60 & 0.493 \\
Leptin ${ }^{\mathrm{b}}(\mathrm{ng} / \mathrm{dl})$ & 1.29 & 0.52 & 3.20 & 0.582 \\
\hline
\end{tabular}

a)Hazard ratios were adjusted for baseline CD4 cell count and HIV viral load; b) More than 25\% of measurements below level quantifiable.

\section{DISCUSSION}

Results of our investigation showed that body mass and some markers of nutrition (albumin, leptin, and hemoglobin) were not related to an increased risk of death in dually-infected participants after initiating anti-tuberculous therapy and ART. Whereas, inflammation as assessed by C-reactive proteins (CRP), pro-inflammatory cytokines, chemokines, and biomarkers of the innate and adaptive immune response were all significantly higher in participants who died than in those who survived for the ensuing year.

The lack of association of nutritional markers in cases of death was somewhat surprising since low BMI, presumably related to inadequate energy intake and incident catabolism/cachexia is not only a risk factor for tuberculosis but also for death, especially in sub-Saharan Africa. In our cohort and the parent study, many of participants were from Sub-Saharan Africa [3] : approximately $50 \%$ had a BMI $<18.5 \mathrm{~kg} / \mathrm{m}^{2}$ and approximately $15 \%$ had a BMI $<16.5 \mathrm{~kg} / \mathrm{m}^{2}$, indicating that they were quite malnourished. Although good nutritional support during early treatment has sound underpinnings $[\underline{30}, \underline{31}]$, our findings do not support the idea that nutritional supplementation during early treatment will favorably affect survival in the following 12 months for treatment-naive participants with HIV and dually-infected with both pathogens. 
Table 3: Markers of Inflammation at Baseline and Association with Risk of Death

\begin{tabular}{|c|c|c|c|c|c|c|}
\hline $\begin{array}{l}\text { Median } \\
(\mathbf{Q} 1, \text { Q3) }\end{array}$ & $\begin{array}{c}\text { Total } \\
(\mathbf{N}=\mathbf{5 1})\end{array}$ & $\begin{array}{l}\text { Deaths } \\
(\mathrm{N}=\mathbf{1 8})\end{array}$ & $\begin{array}{l}\text { Non-deaths } \\
\qquad(\mathbf{N}=\mathbf{3 3})\end{array}$ & $\begin{array}{l}P \text {-value } \\
\text { T-test }^{\text {a }}\end{array}$ & $\begin{array}{c}\text { Hazard Ratio }^{\mathrm{b}}(95 \% \mathrm{CI}) \\
\text { per } 1 \text { IQR increment }\end{array}$ & $\begin{array}{c}P \text {-Value } \\
\text { Wald Test }\end{array}$ \\
\hline CRP (mg/dl) & $9.88(3.46,28.3)$ & $15.4(8.47,50.8)$ & $7.19(2.43,18.2)$ & 0.004 & $3.42(1.33,8.80)$ & 0.011 \\
\hline $\operatorname{IL}-1 \mathrm{RA}^{\mathrm{c}}(\mathrm{ng} / \mathrm{ml})$ & $22.3(2.9,88.4)$ & $41.5(13.2,88.4)$ & $2.9(2.9,82.2)$ & 0.076 & $1.96(0.81,4.73)$ & 0.135 \\
\hline IL-6 (ng/ml) & $6.1(1.3,16.5)$ & $9.8(2.8,20.1)$ & $3.9(0.8,12.2)$ & 0.040 & $2.58(0.79,8.38)$ & 0.115 \\
\hline IL-8 (ng/ml) & $11.5(6.5,21.8)$ & $17.6(11.5,23.9)$ & $9.5(5.9,17.6)$ & 0.024 & $1.94(0.99,3.80)$ & 0.054 \\
\hline IL-10 (ng/ml) & $16.9(3.7,41.5)$ & $37.8(8.0,52.5)$ & $11.5(3.7,23.6)$ & 0.501 & $1.15(0.55,2.43)$ & 0.705 \\
\hline $\mathrm{IL}-15^{\mathrm{d}}(\mathrm{ng} / \mathrm{ml})$ & $0.4(0.4,7.5)$ & $7.0(0.4,8.6)$ & $0.4(0.4,5.7)$ & 0.029 & $2.75(1.08,6.98)$ & 0.033 \\
\hline IL-17 (ng/ml) & $3.2(0.2,13.1)$ & $9.7(1.7,14.9)$ & $1.4(0.2,6.6)$ & 0.025 & $3.99(1.06,15.07)$ & 0.041 \\
\hline IP-10 (ng/ml) & $2.89(1.78,4.72)$ & $3.18(1.75,5.02)$ & $2.51(1.90,4.46)$ & 0.848 & $1.23(0.54,2.82)$ & 0.625 \\
\hline MCP-1 (ng/ml) & $300(224,438)$ & $377(224,590)$ & $299(229,349)$ & 0.256 & $1.89(0.78,4.60)$ & 0.160 \\
\hline $\mathrm{MCP}^{-} 3^{\mathrm{e}}(\mathrm{ng} / \mathrm{ml})$ & $20.6(2.0,36.1)$ & $25.5(16.1,52.7)$ & $11.1(2.0,33.5)$ & 0.027 & $3.67(1.08,12.42)$ & 0.037 \\
\hline MIP (ng/ml) & $34.9(20.7,49.1)$ & $41.9(30.0,49.2)$ & $28.4(14.1,47.8)$ & 0.028 & $1.76(0.95,3.26)$ & 0.073 \\
\hline TNF (ng/ml) & $27.5(17.0,35.6)$ & $34.0(27.5,47.6)$ & $24.0(16.0,30.6)$ & 0.022 & $2.08(0.91,4.77)$ & 0.083 \\
\hline $\operatorname{IFN} \gamma(\mathrm{ng} / \mathrm{ml})$ & $22.5(9.6,38.7)$ & $25.2(15.2,54.4)$ & $21.5(8.2,35.7)$ & 0.038 & $2.46(1.02,5.90)$ & 0.044 \\
\hline Adiponectin (mg/dl) & $3.50(1.86,6.88)$ & $3.48(1.95,5.00)$ & $3.50(1.86,7.11)$ & 0.400 & $0.83(0.46,1.49)$ & 0.528 \\
\hline
\end{tabular}

a) Log10 transformed data were used for statistical analysis; b) Hazard Ratios were adjusted for baseline CD4 cell count and HIV viral load; c, d, e) More than $25 \%$ of measurements below level quantifiable. 
The hazard ratio for CRP, a global measure of inflammation, was more than 3 -fold higher in participants dying than those surviving. Although understanding the specific immune response to clinical tuberculosis is complex, it appears to begin with an innate immune response to tuberculous antigens [32]. This immediate response is mediated by natural killer (NK) lymphocytes that are cytotoxic and lyse autologous infected cells [33-35]. A small fraction of NK cells also secrete IFN $\gamma$ to activate monocytes and macrophages $[\underline{33}, \underline{34}, \underline{36}, \underline{37}]$ to kill intracellular cellular organisms [38-41], both necessary to control bacillary replication. The NK cells upregulate CD8+IF$\mathrm{N} \gamma+$ lymphocytes to stimulate infected monocytes (presumably macrophages as well) to secrete the pro-inflammatory cytokine, IL-15 [42], which is a cardinal marker of the innate immune response, and IL-15 is also upregulated by TLR1/2 signaling during mycobacterial infection to trigger macrophage differentiation [43]. Levels of both IL-15 and INF $\gamma$ were significantly elevated in our study participants who died compared to those who survived.

The adaptive immune response is orchestrated largely by T lymphocytes in response to $M$. tuberculosis [44], which generate cytotoxicity by activated CD8 cells and cytokine secretion [40, 41]; the 2 primary pro-inflammatory cytokines released are INF $\gamma$ and IL-17 [45, 46]. Indeed, most of the IFN $\gamma$ generated during tuberculosis infection is secreted by $\mathrm{T}$ cells and is necessary for the microbicidal function of macrophages to eradicate $M$. tuberculosis $[\underline{40}, \underline{41}, \underline{47}]$. IFN $\gamma$ upregulates IL-17, which is generated by Th-17 cells [요 and among other actions recruits neutrophils to the site of infection [49], mediates macrophage accumulation [ [50], and feeds back to induce Th-1 cells to secrete more IFN $\gamma$ [51]. In our cohort, levels of IL-17, a biomarker of the adaptive immune response, were also increased to a greater degree in participants dying in our study.

The timing and interactions of the innate and adaptive immune systems are complex. Data suggest that NK cells (innate immune response) link these 2 systems by optimizing CD8 lymphocytes (adaptive immune response) to secrete IFN $\gamma$ needed to lyse M. tuberculosis-infected cells [32]. Other data suggest the $\gamma \delta$ T cells (adaptive response), which are preferentially expanded in HIV-infected patients and which secrete pro-inflammatory cytokines including IFN $\gamma$ and IL-17 $[\underline{51}, \underline{52}]$, coordinate and bridge the innate and adaptive immune response [53-57]. Furthermore, IL-15 secreted by phagocytic monocytes during the innate response is a growth factor for $\gamma \delta \mathrm{T}$ cells, promotes cytotoxicity by NK cells, and stimulates their secretion of INF $\gamma$ and TNFa [ [58], thereby linking innate and adaptive immunity during infection with M. tuberculosis [59].

Co-infection with HIV contributes to the complexity of the clinical outcomes and immune response in dual infection with HIV and M. tuberculosis $[\underline{60}, \underline{61}]$. Patients infected with HIV have a greater risk of developing active tuberculosis after exposure to M. tuberculosis and extra-pulmonary disease is associated with more severe HIV immunodeficiency [13]. Conversely, tuberculosis can accelerate HIV infection [ $\underline{62}, \underline{63}]$, and HIV-infected patients co-infected with tuberculosis have shorter survival compared to age- and CD4-matched patients who are HIV-positive but not infected with $M$. tuberculosis $[\underline{62}, \underline{64}]$. In particular, tuberculosis increases HIV viral replication 5-160 fold, primarily in activated T cells [ [65]. Furthermore, HIV and tuberculous co-infection is associated with higher mortality in the setting of low CD4 cell counts [15-17]. Although all participants selected for our case-cohort had low CD4 counts, we still adjusted our baseline measures for CD4 cell counts and HIV viral load. 
In addition, it has recently been demonstrated that mortality in HIV and M. tuberculosis co-infected patients is linked to immune dysfunction of monocytes, especially related to inflammatory mediator production of IL-6,TNFa, and CSF3 and expansion of CD16+CD14+ monocytes [66]. The mechanism that drives this inflammatory response may be through INF $\gamma$ stimulated indolamine 2, 3 dioxygenase (IDO) production by monocytes [67]. In fact, it was recently shown that IDO was a very strong predictive biomarker of active tuberculosis in HIV co-infected patients [68]. We found a significant association between INF $\gamma$ and death in our cohort. Moreover, the kynurenine pathway is an important regulator of both the innate and adaptive immune response [69], which were upregulated in our death cohort. Thus, further studies in our cohort evaluating IDO activity and the levels of kynurenine that results from the breakdown of tryptophan by IDO are warranted.

Our study has several limitations. The case-cohort for whom stored samples were available was relatively small, which limited the power to detect other associations between biomarkers and risk of death. The availability of stored plasma may have potentially introduced bias due to possible differences between participants with and without stored plasma. In addition, the cross-sectional nature does not allow causality to be established, but only generates conceptual linkages by inference for hypothesis testing in future, larger prospective studies. We used multiplex cytokine methodology, whereas individual platform assays may have performed differently for some of the biomarkers, such as for the discrepancy between MCP-1 (not elevated) and MCP-3 (elevated) in cases of death. Yet, there was internal consistency for the immune response to M. tuberculosis as evidenced by significant increases in IFN $\gamma$, IL-15, and IL-17 in cases of death, a profile typical of M. tuberculosis mono-infected patients $[\underline{32}, \underline{53}]$. Indeed, activation of both the innate and adaptive immune responses was exaggerated in our dying participants. Finally, because PBMCs collected from the case-cohort were not viable, we could not measure cellular activation markers.

Regardless, treatment naive participants dying in the months after enrolling in the study had more profound inflammation, which appeared to be globally associated with activation of both innate and adaptive immunity. Future studies that include quantification of different cellular phenotypes and their activation in addition to soluble markers will be needed to unravel the mechanisms underlying our important preliminary observations related to inflammation-associated risk for death in these dually infected patients.

\section{POTENTIAL CONFLICTS OF INTEREST}

None of the authors have conflicts for this manuscript.

\section{ACKNOWLEDGEMENTS}

We are grateful for the patients who agreed to enroll in the study and for the assistance and dedication of the research staff at the ACTG study sites for A5221.

We are grateful for the infrastructure support provided by the Division of AIDS of the National Institutes of Health, Harvard Statistical and Data Analysis Center, and participating Clinical Research Sites. 
Research reported in this publication was supported by the National Institute of Allergy and Infectious Diseases of the National Institutes of Health under Award Number UM1 AI068634, UM1 AI068636 and UM1 AI106701. The content is solely the responsibility of the authors and does not necessarily represent the official views of the National Institutes of Health.

This study is registered with ClinicalTrials.gov number NCT 00108862.

\section{REFERENCES}

1. Ford N, Shubber Z, Meintjes G, Grinsztejn B, Eholie S, Mills EJ, Davies MA, Vitoria M, Penazzato M, Nsanzimana S, Frigati L, O’Brien D, Ellman T, Ajose O, Calmy A, Doherty M. Causes of hospital admission among people living with HIV worldwide: a systematic review and meta-analysis. Lancet HIV. 2015;2(10):e438-44. PubMed PMID: 26423651. doi: 10.1016/S2352-3018(15)00137-X

2. Odone A, Amadasi S, White RG, Cohen T, Grant AD, Houben RM. The impact of antiretroviral therapy on mortality in HIV positive people during tuberculosis treatment: a systematic review and meta-analysis. PLoS One. 2014;9(11):e112017. PubMed PMID: 25391135. Pubmed Central PMCID: 4229142. doi: 10.1371/journal. pone.0112017

3. Havlir DV, Kendall MA, Ive P, Kumwenda J, Swindells S, Qasba SS, Luetkemeyer AF, Hogg E, Rooney JF, Wu X, Hosseinipour MC, Lalloo U, Veloso VG, Some FF, Kumarasamy N, Padayatchi N, Santos BR, Reid S, Hakim J, Mohapi L, Mugyenyi P, Sanchez J, Lama JR, Pape JW, Sanchez A, Asmelash A, Moko E, Sawe F, Andersen J, Sanne I, A ACTGS. Timing of antiretroviral therapy for HIV-1 infection and tuberculosis. N Engl J Med. 2011;365(16):1482-91. PubMed PMID: 22010914. Pubmed Central PMCID: 3327101. doi: 10.1056/NEJMoa1013607

4. Blanc FX, Sok T, Laureillard D, Borand L, Rekacewicz C, Nerrienet E, Madec Y, Marcy O, Chan S, Prak N, Kim C, Lak KK, Hak C, Dim B, Sin CI, Sun S, Guillard B, Sar B, Vong S, Fernandez M, Fox L, Delfraissy JF, Goldfeld AE, Team CS. Earlier versus later start of antiretroviral therapy in HIV-infected adults with tuberculosis. N Engl J Med. 2011;365(16):1471-81. PubMed PMID: 22010913. Pubmed Central PMCID: 4879711. doi: 10.1056/NEJMoa1013911

5. Velasco M, Castilla V, Sanz J, Gaspar G, Condes E, Barros C, Cervero M, Torres R, Guijarro C, Cohort C. Effect of simultaneous use of highly active antiretroviral therapy on survival of HIV patients with tuberculosis. J Acquir Immune Defic Syndr. 2009;50(2):148-52. PubMed PMID: 19131895. doi: 10.1097/QAI.0b013e31819367e7

6. Van Lettow M, Kumwenda JJ, Harries AD, Whalen CC, Taha TE, Kumwenda N, Kang'ombe C, Semba RD. Malnutrition and the severity of lung disease in adults with pulmonary tuberculosis in Malawi. Int J Tuberc Lung Dis. 2004;8(2):211-7. PubMed PMID: 15139450.

7. Lonnroth K, Williams BG, Cegielski P, Dye C. A consistent log-linear relationship between tuberculosis incidence and body mass index. Int J Epidemiol. 2010;39(1):14955. PubMed PMID: 19820104. doi: 10.1093/ije/dyp308 
8. Mupere E, Parraga IM, Tisch DJ, Mayanja HK, Whalen CC. Low nutrient intake among adult women and patients with severe tuberculosis disease in Uganda: a cross-sectional study. BMC Public Health. 2012;12:1050. PubMed PMID: 23217171. Pubmed Central PMCID: PMC3537524. doi: 10.1186/1471-2458-12-1050

9. Zachariah R, Spielmann MP, Harries AD, Salaniponi FM. Moderate to severe malnutrition in patients with tuberculosis is a risk factor associated with early death. Trans $\mathrm{R}$ Soc Trop Med Hyg. 2002;96(3):291-4. PubMed PMID: 12174782.

10. Macallan DC, McNurlan MA, Kurpad AV, de Souza G, Shetty PS, Calder AG, Griffin GE. Whole body protein metabolism in human pulmonary tuberculosis and undernutrition: evidence for anabolic block in tuberculosis. Clin Sci (Lond). 1998;94(3):32131. PubMed PMID: 9616267.

11. Mupere E, Malone L, Zalwango S, Chiunda A, Okwera A, Parraga I, Stein CM, Tisch DJ, Mugerwa R, Boom WH, Mayanja H, Whalen CC. Lean tissue mass wasting is associated with increased risk of mortality among women with pulmonary tuberculosis in urban Uganda. Ann Epidemiol. 2012;22(7):466-73. PubMed PMID: 22575813. Pubmed Central PMCID: 3377556. doi: 10.1016/j.annepidem.2012.04.007

12. Villamor E, Saathoff E, Mugusi F, Bosch RJ, Urassa W, Fawzi WW. Wasting and body composition of adults with pulmonary tuberculosis in relation to HIV-1 coinfection, socioeconomic status, and severity of tuberculosis. Eur J Clin Nutr. 2006;60(2):163-71. PubMed PMID: 16234841. doi: 10.1038/sj.ejcn.1602281

13. Lucas SB, De Cock KM, Hounnou A, Peacock C, Diomande M, Honde M, Beaumel A, Kestens L, Kadio A. Contribution of tuberculosis to slim disease in Africa. BMJ. 1994;308(6943):1531-3. PubMed PMID: 7912597. Pubmed Central PMCID: 2540503

14. van Lettow M, van der Meer JW, West CE, van Crevel R, Semba RD. Interleukin-6 and human immunodeficiency virus load, but not plasma leptin concentration, predict anorexia and wasting in adults with pulmonary tuberculosis in Malawi. J Clin Endocrinol Metab. 2005;90(8):4771-6. PubMed PMID: 15928249. doi: 10.1210/jc.2004-2539

15. Whalen CC, Nsubuga P, Okwera A, Johnson JL, Hom DL, Michael NL, Mugerwa RD, Ellner JJ. Impact of pulmonary tuberculosis on survival of HIV-infected adults: a prospective epidemiologic study in Uganda. AIDS. 2000;14(9):1219-28. PubMed PMID: 10894287. Pubmed Central PMCID: 2869086.

16. Toossi Z, Mayanja-Kizza H, Hirsch CS, Edmonds KL, Spahlinger T, Hom DL, Aung H, Mugyenyi P, Ellner JJ, Whalen CW. Impact of tuberculosis (TB) on HIV-1 activity in dually infected patients. Clin Exp Immunol. 2001;123(2):233-8. PubMed PMID: 11207653. Pubmed Central PMCID: 1905977.

17. Shah S, Whalen C, Kotler DP, Mayanja H, Namale A, Melikian G, Mugerwa R, Semba $\mathrm{RD}$. Severity of human immunodeficiency virus infection is associated with decreased phase angle, fat mass and body cell mass in adults with pulmonary tuberculosis infection in Uganda. J Nutr. 2001;131(11):2843-7. PubMed PMID: 11694606. doi: 10.1093/ jn/131.11.2843

18. Rivera S, Sattler FR, Boyd H, Auffenberg T, Nakao S, Moldawer LL. Urinary cytokines for assessing inflammation in HIV-associated wasting. Cytokine. 2001;13(5):305-13. PubMed PMID: 11243709. doi: 10.1006/cyto.2000.0830 
19. Zackin RA, Clark RA, Currier JS, Mildvan D. Predictive markers of HIV-related weight loss and determination of differences between populations with weight loss stratified by opportunistic processes. J Acquir Immune Defic Syndr. 1999;22(2):18993. PubMed PMID: 10843534.

20. Suttmann U, Ockenga J, Selberg O, Hoogestraat L, Deicher H, Muller MJ. Incidence and prognostic value of malnutrition and wasting in human immunodeficiency virus-infected outpatients. J Acquir Immune Defic Syndr Hum Retrovirol. 1995;8(3):239-46. PubMed PMID: 7859135.

21. Wheeler DA, Gibert CL, Launer CA, Muurahainen N, Elion RA, Abrams DI, Bartsch GE. Weight loss as a predictor of survival and disease progression in HIV infection. Terry Beirn Community Programs for Clinical Research on AIDS. J Acquir Immune Defic Syndr Hum Retrovirol. 1998;18(1):80-5. PubMed PMID: 9593462.

22. Lindan CP, Allen S, Serufilira A, Lifson AR, Van de Perre P, Chen-Rundle A, Batungwanayo J, Nsengumuremyi F, Bogaerts J, Hulley S. Predictors of mortality among HIV-infected women in Kigali, Rwanda. Ann Intern Med. 1992;116(4):320-8. PubMed PMID: 1733389.

23. van der Sande MA, Schim van der Loeff MF, Aveika AA, Sabally S, Togun T, SargeNjie R, Alabi AS, Jaye A, Corrah T, Whittle HC. Body mass index at time of HIV diagnosis: a strong and independent predictor of survival. J Acquir Immune Defic Syndr. 2004;37(2):1288-94. PubMed PMID: 15385737.

24. Kotler DP, Tierney AR, Wang J, Pierson RN, Jr. Magnitude of body-cell-mass depletion and the timing of death from wasting in AIDS. Am J Clin Nutr. 1989;50(3):444-7. PubMed PMID: 2773823. doi: 10.1093/ajcn/50.3.444

25. Gabay C, Kushner I. Acute-phase proteins and other systemic responses to inflammation. N Engl J Med. 1999;340(6):448-54. PubMed PMID: 9971870. 10.1056/ NEJM199902113400607

26. Poli G, Bressler P, Kinter A, Duh E, Timmer WC, Rabson A, Justement JS, Stanley S, Fauci AS. Interleukin 6 induces human immunodeficiency virus expression in infected monocytic cells alone and in synergy with tumor necrosis factor alpha by transcriptional and post-transcriptional mechanisms. J Exp Med. 1990;172(1):151-8. PubMed PMID: 2193094. Pubmed Central PMCID: 2188185.

27. Nakata K, Rom WN, Honda Y, Condos R, Kanegasaki S, Cao Y, Weiden M. Mycobacterium tuberculosis enhances human immunodeficiency virus-1 replication in the lung. Am J Respir Crit Care Med. 1997;155(3):996-1003. PubMed PMID: 9117038. doi: 10.1164/ajrccm.155.3.9117038

28. Wallis RS, Helfand MS, Whalen CC, Johnson JL, Mugerwa RD, Vjecha M, Okwera A, Ellner JJ. Immune activation, allergic drug toxicity and mortality in HIV-positive tuberculosis. Tuber Lung Dis. 1996;77(6):516-23. PubMed PMID: 9039444.

29. Rivera S, Briggs W, Qian D, Sattler FR. Levels of HIV RNA are quantitatively related to prior weight loss in HIV-associated wasting. J Acquir Immune Defic Syndr Hum Retrovirol. 1998;17(5):411-8. PubMed PMID: 9562043. 
30. Paton NI, Chua YK, Earnest A, Chee CB. Randomized controlled trial of nutritional supplementation in patients with newly diagnosed tuberculosis and wasting. Am J Clin Nutr. 2004;80(2):460-5. PubMed PMID: 15277171. doi: 10.1093/ajcn/80.2.460

31. Grobler L, Nagpal S, Sudarsanam TD, Sinclair D. Nutritional supplements for people being treated for active tuberculosis. Cochrane Database Syst Rev. 2016 (6):CD006086. PubMed PMID: 27355911. Pubmed Central PMCID: 4981643. doi: 10.1002/14651858. CD006086.pub4

32. Vankayalapati R, Barnes PF. Innate and adaptive immune responses to human Mycobacterium tuberculosis infection. Tuberculosis (Edinb). 2009;89 Suppl 1:S77-80. PubMed PMID: 20006312. doi: 10.1016/S1472-9792(09)70018-6

33. Gregory SH, Jiang X, Wing EJ. Lymphokine-activated killer cells lyse Listeria-infected hepatocytes and produce elevated quantities of interferon-gamma. J Infect Dis. 1996;174(5):1073-9. PubMed PMID: 8896511.

34. Tay CH, Szomolanyi-Tsuda E, Welsh RM. Control of infections by NK cells. Curr Top Microbiol Immunol. 1998;230:193-220. PubMed PMID: 9586357.

35. Vankayalapati R, Wizel B, Weis SE, Safi H, Lakey DL, Mandelboim O, Samten B, Porgador A, Barnes PF. The NKp46 receptor contributes to NK cell lysis of mononuclear phagocytes infected with an intracellular bacterium. J Immunol. 2002;168(7):3451-7. PubMed PMID: 11907104.

36. Orange JS, Wang B, Terhorst C, Biron CA. Requirement for natural killer cell-produced interferon gamma in defense against murine cytomegalovirus infection and enhancement of this defense pathway by interleukin 12 administration. J Exp Med. 1995;182(4):1045-56. PubMed PMID: 7561678. Pubmed Central PMCID: 2192290.

37. Lucey DR, Clerici M, Shearer GM. Type 1 and type 2 cytokine dysregulation in human infectious, neoplastic, and inflammatory diseases. Clin Microbiol Rev. 1996;9(4):53262. PubMed PMID: 8894351. Pubmed Central PMCID: 172909.

38. Flynn JL, Goldstein MM, Chan J, Triebold KJ, Pfeffer K, Lowenstein CJ, Schreiber $\mathrm{R}$, Mak TW, Bloom BR. Tumor necrosis factor-alpha is required in the protective immune response against Mycobacterium tuberculosis in mice. Immunity. 1995;2(6):561-72. PubMed PMID: 7540941.

39. Chensue SW, Warmington KS, Ruth JH, Lincoln P, Kunkel SL. Cytokine function during mycobacterial and schistosomal antigen-induced pulmonary granuloma formation. Local and regional participation of IFN-gamma, IL-10, and TNF. J Immunol. 1995;154(11):5969-76. PubMed PMID: 7751640.

40. Cooper AM, Dalton DK, Stewart TA, Griffin JP, Russell DG, Orme IM. Disseminated tuberculosis in interferon gamma gene-disrupted mice. J Exp Med. 1993;178(6):22437. PubMed PMID: 8245795. Pubmed Central PMCID: 2191280.

41. Flynn JL, Chan J, Triebold KJ, Dalton DK, Stewart TA, Bloom BR. An essential role for interferon gamma in resistance to Mycobacterium tuberculosis infection. J Exp Med. 1993;178(6):2249-54. PubMed PMID: 7504064. Pubmed Central PMCID: 2191274. 
42. Vankayalapati R, Klucar P, Wizel B, Weis SE, Samten B, Safi H, Shams H, Barnes PF. NK cells regulate CD8+ T cell effector function in response to an intracellular pathogen. J Immunol. 2004;172(1):130-7. PubMed PMID: 14688318.

43. Krutzik SR, Hewison M, Liu PT, Robles JA, Stenger S, Adams JS, Modlin RL. IL-15 links TLR2/1-induced macrophage differentiation to the vitamin D-dependent antimicrobial pathway. J Immunol. 2008;181(10):7115-20. PubMed PMID: 18981132. Pubmed Central PMCID: 2678236.

44. Chen W, Jin W, Hardegen N, Lei KJ, Li L, Marinos N, McGrady G, Wahl SM. Conversion of peripheral CD4+CD25- naive T cells to CD4+CD25+ regulatory T cells by TGF-beta induction of transcription factor Foxp3. J Exp Med. 2003;198(12):187586. PubMed PMID: 14676299. Pubmed Central PMCID: 2194145. doi: 10.1084/ jem.20030152

45. Khader SA, Cooper AM. IL-23 and IL-17 in tuberculosis. Cytokine. 2008;41(2):7983. PubMed PMID: 18218322. Pubmed Central PMCID: 2266085. doi: 10.1016/j. cyto.2007.11.022

46. Khader SA, Pearl JE, Sakamoto K, Gilmartin L, Bell GK, Jelley-Gibbs DM, Ghilardi $\mathrm{N}$, deSauvage F, Cooper AM. IL-23 compensates for the absence of IL-12p70 and is essential for the IL-17 response during tuberculosis but is dispensable for protection and antigen-specific IFN-gamma responses if IL-12p70 is available. J Immunol. 2005;175(2):788-95. PubMed PMID: 16002675.

47. Barnes PF, Lu S, Abrams JS, Wang E, Yamamura M, Modlin RL. Cytokine production at the site of disease in human tuberculosis. Infect Immun. 1993;61(8):3482-9. PubMed PMID: 8335379. Pubmed Central PMCID: 281026.

48. Cruz A, Khader SA, Torrado E, Fraga A, Pearl JE, Pedrosa J, Cooper AM, Castro AG. Cutting edge: IFN-gamma regulates the induction and expansion of IL-17-producing CD4 T cells during mycobacterial infection. J Immunol. 2006;177(3):1416-20. PubMed PMID: 16849446.

49. Jones CE, Chan K. Interleukin-17 stimulates the expression of interleukin-8, growth-related oncogene-alpha, and granulocyte-colony-stimulating factor by human airway epithelial cells. Am J Respir Cell Mol Biol. 2002;26(6):748-53. PubMed PMID: 12034575.

50. Sergejeva S, Ivanov S, Lotvall J, Linden A. Interleukin-17 as a recruitment and survival factor for airway macrophages in allergic airway inflammation. Am J Respir Cell Mol Biol. 2005;33(3):248-53. PubMed PMID: 15901616. doi: 10.1165/rcmb.2004-0213OC

51. Umemura M, Yahagi A, Hamada S, Begum MD, Watanabe H, Kawakami K, Suda T, Sudo K, Nakae S, Iwakura Y, Matsuzaki G. IL-17-mediated regulation of innate and acquired immune response against pulmonary Mycobacterium bovis bacille Calmette-Guerin infection. J Immunol. 2007;178(6):3786-96. PubMed PMID: 17339477.

52. Lockhart E, Green AM, Flynn JL. IL-17 production is dominated by gammadelta T cells rather than CD4 T cells during Mycobacterium tuberculosis infection. J Immunol. 2006;177(7):4662-9. PubMed PMID: 16982905. 
53. Meraviglia S, El Daker S, Dieli F, Martini F, Martino A. gammadelta T cells cross-link innate and adaptive immunity in Mycobacterium tuberculosis infection. Clin Dev Immunol. 2011;2011:587315. PubMed PMID: 21253470. Pubmed Central PMCID: 3022180. doi: 10.1155/2011/587315

54. Poquet Y, Halary F, Champagne E, Davodeau F, Gougeon ML, Bonneville M, Fournie JJ. Human gamma delta T cells in tuberculosis. Res Immunol. 1996;147(8-9):542-9. PubMed PMID: 9127886.

55. Szereday L, Baliko Z, Szekeres-Bartho J. The role of Vdelta2+T-cells in patients with active Mycobacterium tuberculosis infection and tuberculin anergy. Int J Tuberc Lung Dis. 2008;12(3):262-8. PubMed PMID: 18284830.

56. Kabelitz D, Bender A, Prospero T, Wesselborg S, Janssen O, Pechhold K. The primary response of human gamma/delta + T cells to Mycobacterium tuberculosis is restricted to V gamma 9-bearing cells. J Exp Med. 1991;173(6):1331-8. PubMed PMID: 1827825. Pubmed Central PMCID: 2190845.

57. Havlir DV, Ellner JJ, Chervenak KA, Boom WH. Selective expansion of human gamma delta T cells by monocytes infected with live Mycobacterium tuberculosis. J Clin Invest. 1991;87(2):729-33. PubMed PMID: 1899430. Pubmed Central PMCID: 296366. doi: 10.1172/JCI115053

58. Zhang X, Sun S, Hwang I, Tough DF, Sprent J. Potent and selective stimulation of memory-phenotype CD8+ T cells in vivo by IL-15. Immunity. 1998;8(5):591-9. PubMed PMID: 9620680.

59. Casetti R, Martino A. The plasticity of gamma delta T cells: innate immunity, antigen presentation and new immunotherapy. Cell Mol Immunol. 2008;5(3):161-70. PubMed PMID: 18582397. Pubmed Central PMCID: 4651290. doi: 10.1038/cmi.2008.20

60. Daley CL, Small PM, Schecter GF, Schoolnik GK, McAdam RA, Jacobs WR, Jr., Hopewell PC. An outbreak of tuberculosis with accelerated progression among persons infected with the human immunodeficiency virus. An analysis using restriction-fragment-length polymorphisms. N Engl J Med. 1992;326(4):231-5. PubMed PMID: 1345800. doi: 10.1056/NEJM199201233260404

61. Giovanni D, Chiara Danzi M, De Checchi G, Pizzighella S, Solbiati M, Cruciani M, Luzzati R, Malena M, Mazzi R, Concia E, Bassetti D. Nosocomial Epidemic of Active Tuberculosis Among HIV-Infected Patients. The Lancet.334(8678):1502-4. doi: 10.1016/S0140-6736(89)92942-5

62. Whalen C, Horsburgh CR, Hom D, Lahart C, Simberkoff M, Ellner J. Accelerated course of human immunodeficiency virus infection after tuberculosis. Am J Respir Crit Care Med. 1995;151(1):129-35. PubMed PMID: 7812542. doi: 10.1164/ajrccm.151.1.7812542

63. Pape JW, Jean SS, Ho JL, Hafner A, Johnson WD, Jr. Effect of isoniazid prophylaxis on incidence of active tuberculosis and progression of HIV infection. Lancet. 1993;342(8866):268-72. PubMed PMID: 8101302. 
64. Eriki PP, Okwera A, Aisu T, Morrissey AB, Ellner JJ, Daniel TM. The influence of human immunodeficiency virus infection on tuberculosis in Kampala, Uganda. Am Rev Respir Dis. 1991;143(1):185-7. PubMed PMID: 1986677. doi: 10.1164/ajrc$\mathrm{cm} / 143.1 .185$

65. Goletti D, Weissman D, Jackson RW, Graham NM, Vlahov D, Klein RS, Munsiff SS, Ortona L, Cauda R, Fauci AS. Effect of Mycobacterium tuberculosis on HIV replication. Role of immune activation. J Immunol. 1996;157(3):1271-8. PubMed PMID: 8757635.

66. Janssen S, Schutz C, Ward A, Nemes E, Wilkinson KA, Scriven J, Huson MA, Aben N, Maartens G, Burton R, Wilkinson RJ, Grobusch MP, Van der Poll T, Meintjes G. Mortality in Severe Human Immunodeficiency Virus-Tuberculosis Associates With Innate Immune Activation and Dysfunction of Monocytes. Clin Infect Dis. 2017;65(1):7382. PubMed PMID: 28369200. Pubmed Central PMCID: 5849097. doi: 10.1093/cid/ cix 254

67. Jones SP, Franco NF, Varney B, Sundaram G, Brown DA, de Bie J, Lim CK, Guillemin GJ, Brew BJ. Expression of the Kynurenine Pathway in Human Peripheral Blood Mononuclear Cells: Implications for Inflammatory and Neurodegenerative Disease. PLoS One. 2015;10(6):e0131389. PubMed PMID: 26114426. Pubmed Central PMCID: 4482723. doi: 10.1371/journal.pone.0131389

68. Adu-Gyamfi CG, Snyman T, Hoffmann CJ, Martinson NA, Chaisson RE, George JA, Suchard MS. Plasma Indoleamine 2, 3-Dioxygenase, a Biomarker for Tuberculosis in Human Immunodeficiency Virus-Infected Patients. Clin Infect Dis. 2017;65(8):13568. PubMed PMID: 29017244. Pubmed Central PMCID: 5848309. doi: 10.1093/cid/ cix 550

69. Mandi Y, Vecsei L. The kynurenine system and immunoregulation. J Neural Transm (Vienna). 2012;119(2):197-209. PubMed PMID: 21744051. doi: 10.1007/s00702-0110681-y

\section{FOOTNOTES}

Submitted March 23, 2018 | Accepted April 16, 2018 | Published April 26, 2018

\section{COPYRIGHT}

(C) Pathogens and Immunity 2018

This work is licensed under a Creative Commons Attribution 4.0 International License. To view a copy of this license, visit http://creativecommons.org/licenses/by/4.0/ 